УДК 82-2:791

\title{
ІНТЕРМЕДІАЛЬНІСТЬ ЯК ЖАНРОТВОРЧИЙ ФАКТОР (КІНОСЦЕНАРНА СПЕЦИФІКА „КИЇВСЬКИХ ФРЕСОК” СЕРГІЯ ПАРАДЖАНОВА)
}

\section{Наталія Валеріанівна Нікоряк}

nikoriak2008@ukr.net

Кандидат філологічних наук, доцент

Кафедра зарубіжної літератури та теорії літератури Чернівецький національний університет імені Юрія Федьковича Вул. Коцюбинського, 2, 58012, м. Чернівці, Україна

Анотація. В інтермедіальному вимірі аналізується кіносценарна специфіка „Київських фресок” (1965) С. Параджанова. Визначається характер архітектонічно-композиційної організації кіносценарію, інтермедіальні чинники часопростору, персоносфери, зокрема іï палімпсестність. Досліджуються екфрастичні елементи кіносценарного тексту. Порушується питання вектора його сприйняття, що переміщується від самого автора в рецептивну уяву читачів-глядачів.

Ключові слова: С. Параджанов, „Київські фрески”, кіносценарій, композиція, інтермедіальність, екфрасис, палімпсест, рецепція.

Інтермедіальність сьогодні постає однією 3 домінуючих концепцій літературної практики, активізованою науковим простором ще у 50-60-ті рр. минулого століття, хоча сам термін з'явився лише у 80-ті у праці О. Ганзен-Леве (див.: [24]). Зростаючу популярність даної концепції засвідчує чимала кількість праць як вітчизняних $[12 ; 14 ; 16]$, так і зарубіжних учених $[3 ; 4 ; 7 ; 17 ; 18]$. Це можна пояснити ускладненістю принципів організації художніх текстів, які не лише запозичують, інтерпретують, а й асимілюють коди текстів інших видів мистецтва. Текст постає своєрідним „,інформаційним генератором”, що здатен зберігати різноманітні коди, трансформувати отримувані повідомлення й породжувати нові (див.: [10]). Звернення до кодів інших видів мистецтва дозволяє автору повніше себе реалізувати, ,яскравіше виявити своє авторське Я, експериментувати й розширювати зображально-виражальні можливості художнього слова" [16, с. 14].

Таким експериментатором - i y сфері режисури, i як кіносценарист - був С. Параджанов (1924-1990). „Кипуча енергія”

(C) Нікоряк Н., 2013 
митця, за словами І. Дзюби, шукала виходу „в усіх видах творчості, в багатьох мистецтвах" [5, с. 11]. Перший варіант свого літературного сценарію „Київські фрески” С. Параджанов написав 1965 року. Авторський задум було прокоментовано у вступній частині сценарного тексту: „Фільм задуманий мною як кінофреска" $[15$, с. 96], таким чином, визначивши жанр майбутньої стрічки. 3 усього розмаїття кіножанрів автор звернувся до маловідомого на той час в українсько-радянському кіно жанру, який був більш продуктивним на Заході (як відомо, першою історичною кінофрескою вважається робота італійського режисера Джованні Пастроне „Кабірія” (1914)). Проте в українському кінематографі цей жанр став досить популярним саме після кінофресок С. Параджанова (див.: $[2 ; 6])$.

Звернення до живописного жанру для С. Параджанова невипадкове. Автор під час обговорення свого кіносценарію на засіданні редакційно-сценарної колегії зазначав: „Я шукаю фрески життя, намагаючись знайти їх" [11, с. 111]. Режисер стверджував, що „сьогодні легко поставити фільм „Слово о полку Ігоревім”, „значно складніше зробити фільм про сучасність, про нас з вами: як ми живемо, з чим стикаємось, що живе, що руйнується, що приходить на зміну старому, (важче) показати філософію буття" [11, с. 119]. Він вважав, що монументальна форма фресок дозволяє втілити його задум: „Треба замислитися над тим, що $є$ Київ, і створити фільм про нього, про людей, що живуть у ньому, про національний характер. <..> Це фільм про доброту, про гуманність, про клопоти людей. <..> Коли романтичне зіллється 3 побутовим, побутове - 3 епічним, епічне 3 деталями, то це буде фільм-поезія" [11, с. 116-119]. Власне, на тому, що перед нами водночас і поетичний сценарій, наголошувала під час обговорення i редактор В.Саліна: „В ньому органічна поетичність, мислення кадрами-образами, які не занурені кожний в собі, а розростаються в єдиний узагальнений образ. Але ж справжній поетичний образ завжди неоднозначний і не піддається чіткій, суворій інтерпретації, визначенню" [11, с. 113]. Отже, С. Параджанов обрав складний шлях створення свого кіносценарію: він фактично повертався до первісного синкретизму і в одному тексті прагнув злити два види мистецтва - літературу з живописом, наважився свій задум втілити у своєрідній формі фресок як у формі „монументального творіння”.

Принагідно зауважимо, що письменники здавна активно послуговувалися надбаннями живописців. Згадаймо хоча б те, що до пластично-живописної мови вдавалися і романтики (В. Гюго, 
Е. Т. А. Гофман, Т. Шевченко та ін.), і реалістично налаштовані письменники (Ч. Діккенс, О. де Бальзак, М. Гоголь, М. Коцюбинський та ін.), не кажучи про інтермедіальні експерименти модерністів. Логічно, що у ХX ст. до живопису не могли не звернутися й письменники-сценаристи. Джерела зображальних можливостей кіномистецтва видавалися неосяжними. Приміром, С. Ейзенштейн вбачав ці джерела саме у творчості видатних художників світу, зокрема епохи італійського Відродження (див.: [1, с. 24]).

Перших читачів кіносценарію С. Параджанова вражала i водночас захоплювала незвична форма фресок. Про це свідчить, зокрема, висновок членів сценарно-редакційної колегії: „Авторські роздуми про життя, про сучасність, пошуки образно-емоційного їх вираження вилились у задум настільки своєрідний, настільки яскраво індивідуальний, що розглядати і аналізувати його під кутом зору вже звичних уявлень про кіносюжет, сценарну логіку дії неможливо. // Оригінальність, смілива новизна цієї форми полягає насамперед у стислості, сконцентрованості композиції, у складній незвичній пластичній мові сценарію, у несподіваних монтажних стиках, які народжують яскраве асоціативне бачення, гостру кінометафору, нарешті, у складному шифрі ідейної концепції. // I все ж за удаваною хаотичністю фресок, імпресіоністичністю сюжету вимальовуються контури майбутнього фільму, його образ" $[11$, с. 117]. Введення читача-глядача у складний світ асоціацій та кінометафор, які той повинен належним чином прочитувати, розшифровувати й сприймати, постає домінантною ознакою форми. У даному разі читач-глядач мусить не лише бути обізнаним 3 азами кіномистецтва, але й сприйняти цей кіносценарій як текст, що виникає внаслідок переплетення кодів двох видів мистецтва - літератури й живопису. Проте, як зафіксовано у протоколах обговорення сценарію, „декому ця манера літературного запису, що немов зашифровує авторський задум, видається надміру ускладненою і важкою для читання" [11, с. 112], тому автору зрештою радили скористатися послугами письменника, „для остаточного літературного запису” [11, с. 112].

Проте С. Параджанов, будучи геніальним кіноживописцем, органічно надихався саме живописом (див.: [8, с. 60]) - так само, як це робили й інші не менш відомі майстри „екранного живопису”, від С. Ейзенштейна до О. Довженка, які також мали „солідну” практику в галузі малярства. Не лише у „Київських фресках” митець використовує широкий діапазон інтермедіальних маркерів. 
Такі його фільми, як „Колір гранату” (1969), „Легенда про Сурамську фортецю” (1984), „Ашик-Керіб” (1988), не просто вражали своєю мальовничістю, але й були вибудувані саме за законами традиційного живопису. Кожен 3 цих фільмів, як підкреслює С. Безклубенко, являє собою „серію мальовничих „живих" картин, талановито поставлених майстром і „відзнятих” на плівку" [1, с. 26]. Тому цілком слушним поставало зауваження Ю. Іллєнка про те, що „це стиль Параджанова. Це він сам, те, як він бачить життя, в якій площині його роздивляється. Розглядати сценарій окремо від Параджанова не можна" [11, с. 115].

Отже, на прикладі „Київських фресок” послідовно виокремимо характерні інтермедіальні чинники параджанівської кіносценарної практики. Першим інтермедіальним маркером кіносценарію „Київські фрески” постає заголовок, який сконцентрував провідну ідею мистецького твору, сфокусував авторський задум i, врешті, спрямував увагу реципієнта до ключової ідеї твору: повоєнний Київ подається у формі фресок, зокрема, розповідь іде лише про один день 3 життя мешканців столиці - 9 травня. Однак, за зауваженням I. Дзюби, „Київські фрески” мали стати не тільки освідченням у коханні Києву, а й феєричною картиною життя сучасного великого міста, за яким стоїть тисячолітня історія; синтезом його прихованих потенцій” [5, с. 13]. Саме таке змістове наповнення виправдовувало оригінальність форми.

Значущим інтермедіальним кодом постає i eniгpaф кіносценарію. С. Параджанов використав ще один архітектонічний складник тексту - епіграф, який також виступає функціональним ключем до адекватного розуміння авторського задуму. В епіграфі до кіносценарію автор, не вдаючись до інтелектуальної вишуканості, наводить відверто словникове тлумачення слова фреска: „Фреска (італ. fresko). Основне значення - свіжий. Фреска дозволяє створювати монументальні твори, органічно пов'язані 3 архітектурою і часом. // Фреска - палітра фрески досить стримана, що надає їй благородної простоти... // Методи використання фресок змінюються з їх розвитком... (БСЭ, том 45)" [15, с. 96]. 3 розширеної енциклопедичної статті про фреску С. Параджанов вибрав лише ключове. В усіх випадках необов'язковість цього архітектонічного складника робить його наявність у тексті функціонально вкрай важливою. „Епіграф, - підкреслює Н. Фатєєва, - є наступним після заголовка рівнем проникнення в текст, що знаходиться над текстом і співвідноситься з ним як цілим" [21, с. 141]. Виступаючи водночас і як композиційний прийом кінотексту, цей елемент „виконує роль 
експозиції після заголовка, але перед текстом і пропонує пояснення чи загадки для прочитання тексту в його відношенні до заголовка" [21, с. 141]. Епіграф призначений бути прочитаним, тобто він у прямому сенсі робить фільм текстом. Однак, у даному разі, тут спостерігається своєрідна інверсія: як елемент саме інтертекстуальності в межах словесних жанрів, епіграфічна фраза для кінотвору перетворюється вже на елемент інтермедіальності.

Наступним архітектонічним елементом кіносценарної форми, який автор також оригінально використав, постає перелік дійових осіб, не завжди характерний для кіносценарію. Його функція допомогти читачу-глядачу ознайомитися 3 персонажами. Зокрема, С. Параджанов подав спочатку ключових „дійових осіб”: „Людина” - кінорежисер. // „Жінка” - хранителька музею. // „Вантажник” - чоловік 55 років” [15, с. 96], а потім називалися ті, хто з'являється лише „в епізодах”, зокрема, тут це „всі громадяни міста Києва" [15, с. 96].

Зауважимо, що саме персонаж „Людина” об’єднує, зв'язує між собою всі „фрески”, себто всі події, які відбуваються протягом 9 травня 1965 року. Отже, він виступає центральною ланкою кіносценарію. Звертає на себе увагу й той факт, що автор свідомо позбавляє своїх ключових персонажів особистих імен, підкреслюючи символічну узагальненість цих образів. Так, „Людина”, на думку О. Сизоненка, постає як „синтезований образ нашого народу. Образ, створений художником, який увібрав у себе все те, що він бачить 3 висоти свого духовного зору: і бідність, i добрість; розчинена в людському морі, його душа сповнена віри в людей, щедра, чутлива й по-дитячому довірлива. I оця його доброта прочитується в усьому сценаріi”' $[11$, с. 116].

Відзначимо зміну наративної стратегії задуму: у першому режисерському начерку кіносценарію розповідь йшла від першої особи (позиція ліричної настанови тексту), а не від третьої; але зрештою суб'єктивне ,я” трансформувалося на „Людину”. Про це свідчить збережений текст кіносценарію, в якому залишилися місця, де С. Параджанов „я” не виправив: „Людина” розплатилася з водієм i дала „Вантажникові” на „чекушку” - як домовилися... <...> Двірник Фелікс у лакованих туфлях (його всі звали Філя) тріумфував, нарешті він мені услужив, виявив люб'язність (він був упевнений, що 뜨 забув про трансформатора, якого він не повернув). $<\ldots>$ Я вже не слухав його... попрощався й пішов..." [15, с. 100-101]. Отже, як бачимо, ця узагальнена Людина передбачала самого С. Параджанова. 
Натомість деякі другорядні персонажі кіносценарію були поіменовані: зокрема, ім'я двірника - Фелікс, ім'я генеральської доньки - Вікторія й т.п. Таким чином, у персоносфері кіносценарію чітко постає поділ персонажів на „приземлених”, реальних, і „збірних”, символізованих автором. Як підкреслював сам С. Параджанов, „образ вантажника, людини, що прийшла до Києва 3 війни, вдягнувшись вантажником, упродовж ось уже двадцяти років розносить по місту молоко. Це - символ миру, достатку" [15, c. 119]. Відповідно до „малярськоі” техніки фресок, окремі персонажі відтворюються чітко, яскравими фарбами, інші контурно, силуетно. Намагаючись знайти подібність між різними видами мистецтв, Б. Успенський аналізував і специфіку зображення персонажів (див.: [20]). Зокрема, на його думку, другорядні персонажі постають „своєрідним тлом для фігур першого плану”, виконують роль „статистів” у літературному тексті [20, с. 145]. Згідно із цим зауваженням, персоносфера кіносценарію „Київські фрески" потребує окремого акценту: вона має ще й інтермедіальний характер, позаяк проявляється не лише на рівні зображення персонажів, а й в уточненні їхньої професії - кінорежисер, працівниця музею, мистецтвознавець.

Значущої функціональної ваги набуває кіносценарний часопростір, контури якого окреслюються автором чітко: „Місце дії Київ. // Час дії - 9 травня 1965 року" [15, с. 96]. Простір у фресках деталізується: квартира головного персонажа, вулиці Києва, музей мистецтв, квартира „Жінки”, квітковий магазин, площа „Аерофлот” i т.п. Тим самим, обмеживши час дії всього однією добою, редукований хронотоп парадоксальним чином транспонує свої межі в безмежність рецепції. I ця часова обмеженість також підтверджує початковий задум кіносценариста - подати на розсуд читачаглядача „картини життя”, „живописні замальовки”, які схоплені оком художника впродовж одного дня, тому й повинні сприйматися насамперед статично, як статичні компоненти масштабнішого полотна, за відомим зауваженням Г. Лессінга: „...Послідовність у часі є полем докладання зусиль поета, у той час, як простір є полем діяльності художника" [9, с. 64]. Проте кіносценарій - насамперед вербальний художній текст, тому тут статика художнього полотна прочитується як динамічне розгортання сюжету.

На кшталт живопису здійснюється й фрагментація кіносценарію. Сценарний текст складається 3 десяти фресок (без назви), кожна 3 яких має відповідну нумерацію: „Фреска № 1”, „Фреска № 2”, „Фреска № 3”, „Фреска № 4” і далі [15, с. 96-110]. 
Подібна анонімність фрагментів, на наш погляд, аргументується тим, що текст програмує не лише рецептивну налаштованість, але й iii активізацію. Композиція кіносценарію така, що дозволяє збагачувати його новими деталями i новелами-фресками, не порушуючи основи. Отже, епізоди постають перед нами у формі окремих фрескових картин, кожна з яких є завершеним фрагментом цілісної „монументальної композиції”. „Кожна фреска - це шмат людського буття, це немовби висвітлений і відтворений в одну мить фасад тієї будівлі, яку ми звемо життям великого міста. I дійсність наша постає в сценарії так, наче ми іiї бачимо одразу з усіх точок, у багатьох ракурсах", - висловлював своє враження від прочитаного кіносценарію під час його обговорення О. Сизоненко [11, с. 117]. Панорамність режисерського об'єктиву $є$ важливою ознакою та мотивацією всієї архітектонічно-композиційної організації кіносценарію, iї яскраво вираженого інтермедіального характеру.

Малярська тема просякає архітектонічно-композиційну побудову „Київських фресок”. Підкреслимо, що вона виразно акцентується як іспанська. Приміром, „фреска № 2”: „...Музей мистецтв... Інфанта Веласкеса... // Сурбаран... // Гойя... // Моралес..." [15, с. 98]. С. Параджанов не випадково свій перелік музейних експонатів розпочинає 3 „Портрету інфанти Маргарити” (Маргарити Терези Іспанської, 1651-1673, дочки іспанського короля Філіпа IV). Відомий іспанський художник-реаліст епохи бароко, основоположник психологічного портрета в мистецтві Європи Дієго Веласкес був для кіномитця зразковою постаттю художника. Окрім того, „Інфанта” постає тут завперш як просторовий „код” мистецького Києва, який мав точно ідентифікуватися читачем-глядачем. Оригінал цієї картини зберігається в широковідомому Київському музеї західного та східного мистецтва ім. Богдана і Варвари Ханенків - найбільшій українській скарбниці світового мистецтва. У творчому досвіді С. Параджанова, який захоплювався Києвом, де прожив 15 років, цей музей, безперечно, набуває ключової ваги як виняткове джерело.

У сценарії називаються також інші автори, з роботами яких має асоціюватися читацька уява будь-кого з освічених киян. Серед перлин цього музею, зокрема, полотно відомого іспанського художника, представника севільської школи живопису Хуана де Сурбарана „Натюрморт із млинком для шоколаду”, датоване 1640 роком. Представлена й робота іншого іспанського художникаграфіка, згаданого у кіносценарії, Франсиско Гойї „Бравісимо!”. 
Оскільки Гойя увійшов в історію мистецтва насамперед як живописець, який заперечував класичні правила композиції, його техніку варто було б порівняти 3 кінорежисурою С. Параджанова. Список згаданих імен завершується ще одним іспанським живописцем - Луїсом де Моралесом. Таким чином, згадка відомих іспанських художників - Веласкеса, Сурбарана, Гойї, Моралеса у кіносценарії постає як один із екфрастичних елементів тексту, покликаний ,значно розширити просторові і часові межі сприйняття „чужого" образу” [19, с. 60]. Екфрастичні елементи сценарію С. Параджанова активізують духовний та інтелектуальний потенціал читача-глядача, змушеного співвіднести кожне 3 названих імен 3 певною художньою традицією, довідатися, які саме 3 їхніх картин представлені у даному музеї, тим самим „розширити” текст.

Зокрема, кияни, як відомо, пишаються „Інфантою Маргаритою”, унікальним полотном Веласкеса. Цікава історія цього музейного експоната: картину придбав в 1912 р. Богдан Ханенко на розпродажі колекції консула Вебера в Гамбурзі (див.: [13]). У культурному житті тогочасного Києва придбання картини такого масштабу стало великою подією, яка підняла статус Музею мистецтв. У кіносценарії згадка про „Інфанту” з'являється неодноразово: „У склі „Інфанти Маргарити” Веласкеса відбивається обличчя літньої жінки. // Жінка поправляє волосся... гасить світло... // Залп. // Вогні салюту відбиваються у склі „Інфанти Маргарити". // Залп” [15, с. 100]. Зауважимо, що прийом протиставлення чи, навпаки, зближення персонажа і „портрета” в літературі досить поширений. Пригадаймо хоча б „Портрет” М. Гоголя, „Портрет Доріана Грея” О. Уайльда, де портрети функціонують як художні образи [23, с. 104]. С. Параджанов оригінально побудував даний епізод на контрасті: обличчя літньої жінки - молоде личко семилітньої інфанти. Монтажне зближення пластичного образу 3 персонажем запускає процес смислопородження тексту, відбувається асоціативне зближення двох жіночих образів, що підтверджує тезу щодо екфрасису як „не тільки словесного позначення зображення, але й вираженої в ньому рецептивної установки на уяву читача, що відтворює, зокрема, орієнтація його на сприйняття підтексту" $[19$, с. 62]. 3 кіносценарного тексту Маргарита може уявлятися ніби літньою жінкою, хоча померла, як відомо, в двадцятирічному віці.

Важливим елементом інтермедіальності також постає залучення в текст музичної теми. Зокрема, „Фреску № 5” С. Параджанов радить „озвучити інтенцією Баха”, тим самим 
музичний супровід постає емоційним та філософським камертоном до читацької уяви про реальне життя „Жінки”, конотоване ірреальним буттям „Інфанти”. Органічність даного фрагмента будується на постійному чергуванні образу буденного життя 3 психологічною реальністю снів та спогадів:

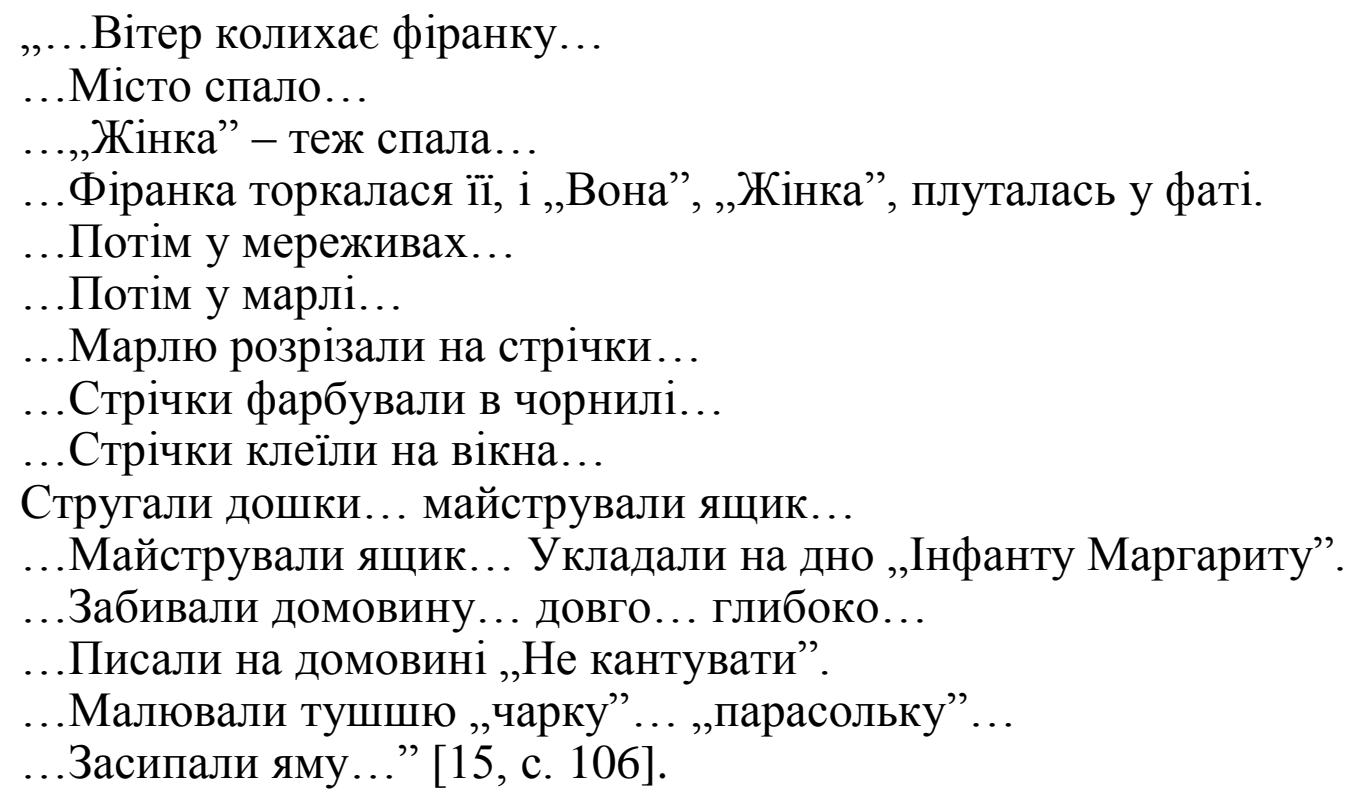

Попри зовнішню мозаїчність ця фреска має безперечну внутрішню цілісність. Сцена складається 3 кількох епізодів, які завдяки продуманим монтажним переходам плавно перетікають один в одного, підсилюючи тим самим сугестивний ефект та філософський підтекст даної сцени. В уяві читача-глядача постає фрагмент $з$ життя „Жінки”, хранительки музею, яка втратила на війні чоловіка і присвятила своє життя „служінню красі”. Закономірно, що цей момент був відзначений і під час обговорення сценарію: „Чудовий монтажний перехід <..> Він динамічний, створює напругу, ритм. Знайдено диптих: людям сниться війна. Монтажний перехід через завісу - фату: героїня згадує молодість, евакуацію - „Інфанту” Веласкеса ховають у ящик” [11, с. 111-112]. Отже, ця фреска ніби подає нам фрагменти життя „Жінки”, але крізь нього проступає, наче у палімпсесті, картина життя Маргарити. Білий колір - колір „фати”, „мережива”, і зрештою „марлі” плавно переходить у чорний - колір трауру, смерті. Загальновідомо, що зовсім юною, у 14 років інфанту Маргариту видали заміж за імператора Священної Римської імперії Леопольда І. Їхній шлюб тривав лише шість років, протягом яких вона народила своєму чоловікові шістьох дітей, з яких вижила лише дочка. Зрештою, у 21-річному віці, виснажена хворобами і смертями, Маргарита 
померла. Цей своєрідний палімпсест розкриває авторську ідею про відносність будь-яких життєвих цінностей загалом.

Дана „фреска" показує С. Параджанова справжнім істориком, а також тонким знавцем мистецтва. Оскільки найбільше запитань під час обговорення кіносценарію було саме до цього фрагмента, він намагався пояснити свій задум представникам радянської цензури 3 „Інфантою” (як це залишилося в протокольному записі) так: „Інфанта” Веласкеса належить народам. Це - шедевр. Фільм - це своєрідний портрет. „Інфанта” Веласкеса, за композицією, перерізана до пояса, але оживає. Я проходжуся 3 апаратом. „Інфанта" у вишуканій рамі. Я бачу, як проходить інфанта. Я входжу до майстерні Веласкеса. Я бачу Веласкеса. З'являється образ дівчини. Вона вичавлює скло своїми черевичками. Вона повинна розуміти цю жінку. Коли забивали труну інфанти, ця жінка кладе туди портрет чоловіка" [11, с. 131]. Як бачимо, використання С. Параджановим екфрасису має надзвичайно конструктивну вагу для всієї цілісної структури його сценарію, справляє ефект ланцюгових, послідовних переходів від однієї теми до іншої.

Так, до музею мистецтв текст приведе нас ще один раз наприкінці „фрески № 9”, де ми спостерігаємо за підготовкою до прийому відвідувачів: „Музей... Рука відкриває Кассоне (скриню V сторіччя - Іспанія) і ставить у куток пляшку з молоком... // У довгій анфіладі хранительки музею знімали порох із шедеврів... натирали суконками підлогу... // Жінка сіла під „Інфантою Маргаритою” i затулила долонею обличчя... здавалося, що вона задрімала..." [15, с. 110]. Відвідувачі обов'язково приходитимуть у музей у святковий день, де не лише побачать живописні шедеври, а й рукотворні такі, наприклад, як ця скриня Кассоне, що й відбувається у наступній, останній ,фресці № 10”, яку варто навести цілком, аби не порушити внутрішньої єдності даного фрагмента кіносценарію:

„...Пуста рама... 3 написом „Веласкес”.

...Натирають підлогу хранительки музею...

...Натирає підлогу юна інфанта Маргарита...

...Вона посміхається до „Жінки”, що спить...

...Здається, що інфанта танцює „Галзарду”...

...Вона вклоняється „Жінці”, тягнеться до неї рукою...

...,ЖЖінка" здригається...

...Один за одним ідуть сходами уверх солдатські чоботи...

... Чоботи переходять із зали в залу...

Спить „Жінка”...

...Чоботи минають „Жінку”, що спить... 

один одного...

...Чоботи різко збавляють крок... пливуть навшпиньки, осаджують

...зупиняються перед „Інфантою”...

Голос мистецтвознавця...

- Станьте до кола... „Інфанта Маргарита”, Веласкес... Іспанія... Прошу уваги... Душевна краса юної інфанти... iї сонячний колорит... Фактура шовку... волосся передані з великою реалістичною силою... Очі відбивають душевний стан юного створіння... Інфанта дивиться у віки... як символ краси й захвату...

...Солдати відбиваються у склі шедевра, вглядаються в себе, поправляють волосся... обсмикують паски... випинають груди... підштовхують один одного... потім повільно повертають голови...

...Навстіж відчинене вікно... дві босі дівчини, викручуючи ганчірки, змивають порох з віконного скла... каштанів...

...Вітер гойдає їхні силуети... вони заплутані у весняних вітах

...Ллється вода по склу... в ньому відбиваються

...Весна

...Інфанта

...Червоні колони

...Кобзар..." [15, с. 110].

Саме ця бездоганна фреска підносить С. Параджанова на вершину майстерності, тут активізація екфрастичних елементів, злиття двох мистецтв сягає своєї найвищої точки і справляє на читача-глядача вражаючий ефект.

На думку О. Фрейденберг, екфрасис „прагне показати, що мертва річ, створена майстерним художником, має вигляд живої”, вона ,зображує одне, ілюзорне, як інше, реальне” [22, с. 250]. Цей момент підтверджує основну тезу автора - минуле співіснує із сьогоденням, оживає в ньому. Вже у першому фрагменті фрески автор вдається до прийому „оживлення” зорового образу: юна інфанта не лише посміхається, а виходить 3 рами й разом 3 працівницями музею береться за прибирання.

У наступному фрагменті, як бачимо, автор вдається до т.зв. „музейного екфрасису”, тобто „опису музейного споглядання творів мистецтва" (див.: [25]). Перед нами постають відвідувачі музею, які бездумно стоять перед веласківським полотном (тут це „солдатські чоботи”), скоріше вдивляючись у власні відображення. Водночас вони „ніби” слухають коментар мистецтвознавця, який висловлює своє компетентне бачення шедевру Веласкеса. Але насправді С. Параджанов зміщує тут рецептивний вектор з безликих „чоботів” на реальну глядацьку публіку: їй надається унікальна можливість також пройтися залами музею мистецтв і сприйняти 
згадані шедеври, збагнути сказане екскурсоводом, зробити власні висновки.

Отже, специфічна архітектонічно-композиційна організація розглянутого кіносценарію С. Параджанова репрезентує яскраво виражений інтермедіальний характер, інтермедіальність тут постає ключовим жанротворчим фактором тексту. Використання окреслених інтермедіальних маркерів свідчить не тільки про багатогранність, унікальність та естетичний модус кіномитця. „Розкодування” інтермедіального виміру має провідне положення в адекватному прочитанні його авторського задуму, розумінні справжнього ідейного підтексту твору, свідчить про багатошарову, надзвичайно потужну складність рецептивного потенціалу „Київських фресок”.

1. Безклубенко С. Д. Відеологія. Основи теорії екранних мистецтв / Сергій Данилович Безклубенко. - К. : Альтерпрес, 2004. - 328 с.

2. Брюховецька Л. Фільм як результат чаклунства [Електронний ресурс] / Лариса Брюховецька // День. - 3 червня 2011 р. - № 95. - Режим доступу : http://www.day.kiev.ua/uk/article/kultura/film-yak-rezultatchaklunstva.

3. Вайсштайн У. Порівняння літератури 3 іншими видами мистецтва : сучасні тенденції та напрями дослідження в літературознавчій теорії та методології / Ульріх Вайсшайн // Сучасна літературна компаративістика: стратегії і методи : антологія / [за заг. ред. Дмитра Наливайка]. - К. : Вид. дім „Києво-Могилянська академія”, 2009. C. 372-392.

4. Вислоух С. Література й візуальний образ. Простір структурної спільності мистецтв / Северина Вислоух // Теорія літератури в Польщі: друга половина XX - початок XXI ст. : антологія текстів / [упоряд. Б. Бакули ; за заг. ред. В. Моренця] ; пер. 3 пол. С. Яковенка. - К. : Вид. дім „Києво-Могилянська академія”, 2008. - С. 309-321.

5. Дзюба I. Він ще повернеться в Україну / Іван Дзюба // Сергій Параджанов: Злет, трагедія, вічність : Твори, листи, документи архівів, спогади, статті, фотографії / [упоряд. Р. М. Корогодський, С. І. Щерба]. К. : Спалах, 1994. - С. 8-15.

6. Зубавіна I. Б. Кінематограф незалежної України : тенденції, фільми, постаті / І. Б. Зубвіна. - К. : ФЕНІКС, 2007. - 296 с.

7. Кайда Л. Г. Интермедиальное пространство композиции : [монография] / Л. Г. Кайда. - М. : ФЛИНТА ; Наука, 2013. - 174 с.

8. Корогодський Р. „Рік життя біля джерела натхнення” / Роман Корогодський // Сергій Параджанов: Злет, трагедія, вічність : Твори, листи, документи архівів, спогади, статті, фотографії / [упоряд. Р. М. Корогодський, С. І. Щерба]. - К. : Спалах, 1994. - С. 59-95. 
9. Лессінг Г. Е. Лаокоон, або Про межі малярства й поезії / Г. Е. Лессінг. К. : Мистецтво, 1968. - 290 с.

10. Лотман Ю. М. Избранные статьи : в 3 т. T.I. Статьи по семиотике и типологии культуры / Ю. М. Лотман. - Таллин : Александра, 1992. $480 \mathrm{c}$.

11. Матеріали до історії створення сценарію „Київські фрески” // Сергій Параджанов: Злет, трагедія, вічність: Твори, листи, документи архівів, спогади, статті, фотографії / [упоряд. Р. М. Корогодський, С. І. Щерба]. К. : Спалах, 1994. - С. 111-148.

12. Мочернюк Н. Д. Художній простір у контексті інтермедіальності (поезія та образотворче мистецтво) / Н. Д. Мочернюк // Питання літературознавства : науковий збірник / гол. ред. О. В. Червінська. Чернівці : Чернівецький нац. ун-т, 2013. - Вип. 87. - С. 219-229.

13. Музей мистецтв ім. Богдана та Варвари Ханенків : історія зібрання [Електронний ресурс]. - Режим доступу: http://www.khanenkomuseum. kiev.ua/ua/History/Historyofcollection.htm.

14. Наливайко Д. Література в системі мистецтв як галузь компаративістики / Дмитро Наливайко // Літературна теорія і компаративістика. - Харків : Акта, 2006. - 366 с.

15. Параджанов С. Київські фрески : [сценарій] / Сергій Параджанов // Сергій Параджанов: Злет, трагедія, вічність: Твори, листи, документи архівів, спогади, статті, фотографії / [упоряд. Р. М. Корогодський, С. І. Щерба]. - К. : Спалах, 1994. - С. 96-110.

16. Просалова B. Інтермедіальність у системі інтертекстуальних зв’язків / Віра Просалова // Актуальні проблеми української літератури i фольклору : наук. зб. - Вип. 15 / [редкол. : В. А. Просалова (відп. ред.) та ін.] - Донецьк : Норд-Прес, 2010. - С. 13-19.

17. Профе О.О. Взаимодействие литературы и живописи в ранней драматургии Мориса Метерлинка : дисс. ... канд. філол. наук : 10.01.03 / Ольга Александровна Профе. - СПб, 2005. - 234 с.

18. Тишунина Н. В. Методология интермедиального анализа в свете междисциплинарных исследований / Н.В. Тишунина // Методология гуманитарного знания в перспективе XX века. К 80-летию проф. М.С. Кагана. Материалы международной научной конференции. СПб. : Санкт-Петербургское философское общество, 2001. - Вып. 12. C. 149-154.

19. Уртмінцеева М. Екфразис як рецептивна установка тексту (до проблеми організації художнього простору) / Марина Уртмінцева // Екфразис : Вербальні образи мистецтва : [монографія] / за ред. Т. Бовсунівської ; пер. 3 англ. І. Малішевської, $з$ пол. та рос. Д. Литовченка. - К. : ВПЦ „Київський університет”, 2013. - С. 47-62.

20. Успенский Б. Семиотика искусства / Борис Успенский. - М. : Языки русской культуры, 1995. - С. 167-212.

21. Фатеева Н. A. Интертекст в мире текстов: Контрапункт интертекстуальность / Наталья Александровна Фатеева ; [изд. 3-е, стереотипное]. - М. : КомКнига, 2007. - 280 с. 
22. Фрейденберг О. М. Миф и литература древности / О. М. Фрейденберг ; [сост., подг. текстов, коммент. и послесл. Н. В. Брагинской; отв. ред. Е. М. Мелетинский . - 2-е изд., испр. и доп.]. - М. : Изд. фирма „Вост. лpa" РAH, 1998. - 800 c.

23. Шахова К. О. Образотворче мистецтво і література (Літературнокритичний нарис) / К. О. Шахова. - К. : Дніпро, 1987. - 195 с. - (Бесіди про художню літературу).

24. Hansen-Löve $A$. Intermedialität und Intertextualität: Probleme der Korrelation von Wort und Bildkunst - am Beispiel der russischen Moderne / A. Hansen-Löve // Wiener Slawistischer Almanach. - Sbd. 11. - Wien, 1983. - S. 291-360.

25. Calamity J. Conventions of ekphrasis [Electronic resource] / Jane Calamity. Available at : http://calamity.wordherders.net/archives/000422.html.

\title{
ИНТЕРМЕДИАЛЬНОСТЬ КАК ЖАНРОТВОРЧЕСКИЙ ФАКТОР (КИНОСЦЕНАРНАЯ СПЕЦИФИКА „КИЕВСКИХ ФРЕСОК” СЕРГЕЯ ПАРАДЖАНОВА)
}

\author{
Наталья Валериановна Никоряк \\ nikoriak2008@ukr.net \\ Кандидат филологических наук, доиент \\ Кафедра зарубежной литературы и теории литературы \\ Черновицкий национальный университет имени Юрия Федьковича \\ Ул. Кочюбинского, 2, 58012, г. Черновцы, Украина
}

\begin{abstract}
Аннотация. В интермедиальном измерении анализируется киносценарная специфика „Киевских фресок” (1965) С. Параджанова. Отмечается характер архитектонически-композиционной организации киносценария, интермедиальные факторы времени и пространства, персоносферы, в частности палимпсестность. Исследуются также экфрастические элементы киносценарного текста. Поднимается вопрос вектора его восприятия, что перемещается от автора в рецептивное воображение читателей-зрителей.

Ключевые слова: С. Параджанов, „Киевские фрески”, киносценарий, композиция, интермедиальность, экфрасис, палимпсест, рецепция.
\end{abstract}

\section{INTERMEDIALITY AS A GENRE-SPECIFIC FACTOR (SERGII PARAJANOV'S “KYIV FRESCOES" ("KYIVS'KY FRESKY") SCRIPT SPECIFICITY)}

\author{
Natalia Nikoryak \\ nikoriak2008@ukr.net \\ The Department of World Literature and Theory of Literature \\ Yuriy Fedkovych Chernivtsi National University \\ 2 Kotsiubynskiy Street, 58012, Chernivtsi, Ukraine
}


Abstract. The purpose of this research is to study intermediality as one of the dominant concepts of literary practice in recent years (N. Tishunina, L. Khaida, O. Profe, N. Mocherniuk, V. Prosalova etc.) by the example of Sergii Parajanov's "Kyiv Frescoes" ("Kyivs'ky Fresky") script text. The topicality of this theme emanates from the need to analyze screenplay intermedial codes, including intermedial nature of text architectonic and composition organization, personal sphere and chronotope intermediality, as well as screenplay ekphractic elements and constructive palimpsest. In the text of this screenplay, intermediality appears to be a genre-specific factor. Research methodology is based on complex tools of modern approaches to the separation and analysis of new literary forms for which the state of intermedial contextuality (set of structural and semantic principles, genre studies discourse, and receptive poetics practice).

Use of intermediality markers is stipulated by the film author's desire to return to the art's original syncretism. In addition, the text intermedial dimension represents the screenwriter's aesthetic modus, specifically, the Spanish context of the screenplay, as well as the artist's own receptive and productive needs and the productivity of his impressions of other artists' works. Intermedial discourse constitutes a specific hermeneutic resource that can not be ignored. Intermedial codes of S. Parajanov's screenplay reflect the general practice of screenplay text creating. This is the usage of this component that extremely enriches the literary text, thus involving it in an active dialogue with other art forms. "Decoding" of the text intermedial dimension has prime importance for the author's conception disclosure and adequate understanding of the implications. In addition, the role intermedial markers are called for is to awaken creative, associative readerviewer's thinking, encourage him/her to adequate creative reflections.

Key words: S. Parajanov, "Kyiv Frescoes" ("Kyivs'ky Fresky"), script, composition, intermediality, ekphrasys, palimpsest, reception.

\section{References}

1. Bezklubenko S. D. Videolohiia. Osnovy teorii ekrannykh mystetstv [Videology. Fundamentals of Screen Arts]. Kyiv, 2004, 328 p. (in Ukrainian).

2. Briukhovets'ka L. Fil'm iak rezul'tat chaklunstva [Movie as a Magic Design]. Den', 3 June 2011, no. 95. Available at: http://www.day.kiev.ua/uk/ article/kultura/film-yak-rezultat-chaklunstva (accessed 12 September 2013). (in Ukrainian).

3. Vaisshtain U. Porivniannia literatury z inshymy vydamy mystetstva: suchasni tendentsii ta napriamy doslidzhennia $\mathrm{V}$ literaturoznavchii teorii ta metodolohiï [Literature as Compared to Other Arts: Modern Tendencies and Trends of Research in Theory of Literature and Methodology]. In: Suchasna literaturna komparatyvistyka: stratehii $i$ metody. Kyiv, 2009, pp. 372-392. (in Ukrainian).

4. Vysloukh S. Literatura i vizual'nyi obraz. Prostir strukturnoï spil'nosti mystetstv [Literature and Visual Image. Field of Arts Structure Community]. In: Teoriia literatury $v$ Pol'shchi: druha polovyna XX - pochatok XXI st. Kyiv, 2008, pp. 309-321. (in Ukrainian). 
5. Dziuba I. Vin shche povernet'sia v Ukraïnu [He Will Come Back to Ukraine Once Again]. In: Serhii Paradzhanov: Zlet, trahediia, vichnist': Tvory, lysty, dokumenty arkhiviv, spohady, statti, fotohrafii. Kyiv, 1994, pp. 8-15. (in Ukrainian).

6. Zubavina I. B. Kinematohraf nezalezhnoï Ukrä̈ny: tendentsï, fil'my, postati [Cinematograph of Independent Ukraine: Trends, Movies, Figures]. Kyiv, 2007, 296 p. (in Ukrainian).

7. Kaida L. G. Intermedial'noe prostranstvo kompozitsii [Intermedial Space of Composition: monograph]. Moscow, 2013, 174 p. (in Russian).

8. Korohods'kyi R. "Rik zhyttia bilia dzherela natkhnennia" ["A Year of Life at the Source of Inspiration"]. In: Serhii Paradzhanov: Zlet, trahediia, vichnist': Tvory, lysty, dokumenty arkhiviv, spohady, statti, fotohrafii. Kyiv, 1994, pp. 59-95.

9. Lessinh H. E. Laokoon, abo Pro mezhi maliarstva i poezii [Laocoon: or, The limits of Poetry and Painting]. Kyiv, 1968, 290 p.

10. Lotman Iu. M. Izbrannye stat'i: v 3 t. T.I. Stat'i po semiotike $i$ tipologii kul'tury [Selected Articles: in three volumes. V. I. Articles on Semiotics and Typology of Culture]. Tallinn, 1992, 480 p. (in Russian).

11. Materialy do istoriï stvorennia stsenariiu "Kyïvs'ki fresky" [Materials on the History of "Kyiv Frescoes” Script Creation]. In: Serhii Paradzhanov: Zlet, trahediia, vichnist': Tvory, lysty, dokumenty arkhiviv, spohady, statti, fotohrafiï. Kyiv, 1994, pp. 111-148.

12. Mocherniuk N. D. Khudozhnii prostir u konteksti intermedial'nosti (poeziia ta obrazotvorche mystetstvo) [Art Space in the Context of Intermediality (Poetry and Fine Arts)]. Pytannia literaturoznavstva, 2013. no. 87, pp. 219-229. (in Ukrainian).

13. Muzei mystetstv im. Bohdana ta Varvary Khanenkiv: istoriia zibrannia [Bohdan and Varvara Khanenko Arts Museum: history of the collection]. Available at: http://www.khanenkomuseum.kiev.ua/ua/History/ Historyofcollection.htm (accessed 12 September 2013). (in Ukrainian).

14. Nalyvaiko D. Literatura v systemi mystetstv iak haluz' komparatyvistyky [Literature in the System of Arts as a Branch of Comparative Studies]. In: Literaturna teoriia i komparatyvistyka. Kharkiv, 2006, 366 p. (in Ukrainian).

15. Paradzhanov S. Kyïvs'ki fresky [Kyiv Frescoes]. In: Serhii Paradzhanov: Zlet, trahediia, vichnist': Tvory, lysty, dokumenty arkhiviv, spohady, statti, fotohrafii. Kyiv, 1994, pp. 96-110. (in Ukrainian).

16. Prosalova V. Intermedial'nist' u systemi intertekstual'nykh zviazkiv [Intermediality in the System of Intertextual Connections]. Aktual'ni problemy ukraïns'koï literatury i fol'kloru. Donetsk, 2010, no. 15, pp. 13-19. (in Ukrainian).

17. Profe O. O. Vzaimodeistvie literatury $i$ zhivopisi v rannei dramaturgii Morisa Meterlinka [Interaction of Literature and Painting in the Early Plays of Maurice Maeterlinck]. PhD dissertation (Literatura narodov stran zarubezh'ia). St. Petersburg, 2005, 234 p. (in Russian).

18. Tishunina N. V. Metodologiia intermedial'nogo analiza v svete mezhdistsiplinarnykh issledovanii [Methodology of Interemedial Analysis in the Light of Interdisciplinary Research]. In: Metodologiia gumanitarnogo 
znaniia v perspektive XX veka. K 80-letiiu prof. M. S. Kagana. Materialy mezhdunarodnoi nauchnoi konferentsii. St. Petersburg, 2001, vol. 12, pp. 149-154. (in Russian).

19. Urtmintseva M. Ekfrazys iak retseptyvna ustanovka tekstu (do problemy orhanizatsiï khudozhn'oho prostoru) [Ekphrasis as A Text's Receptive Aim (on the issue of art space organization)]. In: Ekfrazys: Verbal'ni obrazy mystetstva. Kyiv, 2013, pp. 47-62. (in Ukrainian).

20. Uspenskii B. Semiotika iskusstva [Semiotics of Art]. Moscow, 1995, pp. 167-212. (in Russian).

21. Fateeva N. A. Intertekst $v$ mire tekstov: Kontrapunkt intertekstual'nost' [Inertext in the World of Texts: Counterpoint of Intertextuality]. Moscow, 2007, 280 p. (in Russian).

22. Freidenberg O. M. Mif i literatura drevnosti [Myth and Literature of Antiquity]. Moscow, 1998, 800 p. (in Russian).

23. Shakhova K. O. Obrazotvorche mystetstvo $i$ literatura (Literaturnokrytychnyi narys) [Fine Arts and literature (critical essay)]. Kyiv, 1987, 195 p. (in Ukrainian).

24. Hansen-Löve A. Intermedialität und Intertextualität: Probleme der Korrelation von Wort und Bildkunst - am Beispiel der russischen Moderne. Wiener Slawistischer Almanach. Wien, 1983, Sbd. 11, pp. 291-360.

25. Calamity J. Conventions of ekphrasis. Available at: http://calamity. wordherders.net/archives/000422.html (accessed 12 September 2013).

\section{Suggested citation}

Nikoryak N. Intermedial'nist' iak zhanrotvorchyi faktor (kinostsenarna spetsyfika „Kyïvs'kykh fresok” Serhiia Paradzhanova) [Intermediality as a GenreSpecific Factor (Sergii Parajanov's "Kyiv Frescoes" ("Kyivs'ky Fresky") Script Specificity)]. Pytannia literaturoznavstva, 2013, no. 88, pp. 351-367. (in Ukrainian).

Стаття прийнята до друку 14.11.2013 р. 